\title{
Student Perceptions Analysis of Online Learning: A Machine Learning Approach
}

\author{
H Suparwito*', A M Polina², M Budiraharjo ${ }^{3}$ \\ ${ }^{1,2}$ Informatics Department, Universitas Sanata Dharma, Indonesia \\ ${ }^{3}$ English Education Department, Universitas Sanata Dharma, Indonesia \\ E-mail: shirsj@jesuits.net ${ }^{1}$, a.m.polina@usd.ac.id², mbudiraharjo1@usd.ac.id ${ }^{3}$
}

Submitted: 30 June 2021, revised: 30 July 2021, accepted: 3 August 2021

\begin{abstract}
Abstrak. Pandemi Covid-19 yang saat ini terjadi berdampak pada hampir semua aspek kehidupan, termasuk pendidikan. School from Home (SFH) merupakan salah satu cara untuk mencegah penyebaran Covid-19. Metode pembelajaran tatap muka di kelas berubah menjadi pembelajaran daring dengan menggunakan fasilitas teknologi informasi. Meskipun banyak kendala dalam pelaksanaan kelas daring, pembelajaran ini memberikan perspektif baru bagi pembelajaran siswa. Salah satu faktor keberhasilan proses pembelajaran daring adalah interaksi antara dua aktor utama dalam proses pembelajaran, yaitu dosen dan mahasiswa. Berkaitan dengan situasi tersebut, penelitian ini bertujuan untuk menganalisis persepsi siswa terhadap proses pembelajaran daring. Data penelitian diperoleh dari angket siswa, yang meliputi lima kriteria utama dalam proses pembelajaran: 1) aspek manajemen diri, 2) upaya pribadi, 3) pemanfaatan teknologi, 4) persepsi peran diri, dan 5) persepsi peran dosen. Siswa diberikan penilaian melalui angket tentang metode pembelajaran online yang mereka alami selama pandemi Covid-19. Algoritma random forest diterapkan untuk memeriksa data. Hasil penelitian difokuskan pada tiga kriteria utama (variable importance) yang mempengaruhi persepsi siswa terhadap proses pembelajaran daring. Hasil penelitian menggambarkan bahwa kepuasan mahasiswa dalam pembelajaran daring dipengaruhi oleh 1) Hubungan antara mahasiswa dan dosen. 2) Materi pembelajaran perlu diubah dan disesuaikan dengan metode pembelajaran daring; 3) Penggunaan teknologi untuk mengakses pembelajaran daring. Studi ini memberikan kontribusi untuk meningkatkan metode pembelajaran daring bagi siswa.
\end{abstract}

Kata kunci: educational data mining; machine learning; pembelajaran daring; prediksi; variable importance

\begin{abstract}
The Covid-19 pandemic is currently occurring effects almost all aspects of life, including education. School from Home (SFH) is one of the ways to prevent the spread of Covid-19. The face-to-face learning method in class turns into online learning using information technology facilities. Even though there are many barriers to implementing the class online, online learning provides a new perspective for students' learning. One of the factors for the online learning process's success is the interaction between the two main actors in the learning process, i.e., lecturers and students. Concerning to the situation, this study aims to analyze students' perceptions of the online learning process. The research data were obtained from a student questionnaire, which included five main criteria in the learning process: 1) self-management aspects, 2) personal efforts, 3) technology utilization, 4) perceptions of self-roles, and 5) perceptions of the role of the lecturer. Students were provided with an assessment through a questionnaire about the online learning methods they
\end{abstract}


experienced during the Covid-19 pandemic. The random forest algorithm was applied to examine data. The study results were focused on three main criteria (variable importance) that affect students' perceptions of the online learning process. The results described that the students' satisfaction in online learning is influenced by 1) The relationship between students and lecturers. 2) The learning materials need to be changed and adapted to the online learning method; 3) The use of technology to access online learning. The study contributes to improving the online learning method for the student.

Keywords: educational data mining; machine learning; online learning; prediction; variable importance

\section{Introduction}

In early March 2020, the Indonesia Government officially announced the first case of Corona Virus (Covid-19) in Indonesia. The Covid-19 pandemic has affected almost all human aspects, such as health, economy, social, culture, technology, and education. Notably, in education, schools are closed, and an online learning process is implemented. Even though many schools and universities have used online learning in the daily learning process, this condition challenges and must be faced by lecturers, students, and all stakeholders. Some of the challenges faced include:

1. Face-to-face forms in the classroom become digital forms (e-learning). Lecturers are appealed to deliver learning materials online effectively so that students could understand well.

2. Regarding many practicum courses in the laboratory, online learning for this practicum class has never been imagined or anticipated before.

3. The issue of capacity in utilization and readiness to use information technology is also challenging.

4. In terms of internet access, it requires internet access if the learning is carried out through video conferencing. On the student side, this also has financial consequences.

These challenges emerged a big question in the effectiveness of online learning methods. This study raised three crucial questions: the students' perceptions of the online learning method and how effective online learning is. Firstly, could the machine learning method be used to determine student perceptions of the online learning process? This perception has three criteria: students' perceptions of online lectures, the roles of students and lecturers, and the relation to access and use of information technology. Secondly, do students desire the main criteria (variable importance) to affect their online learning process perceptions? Thirdly, the survey was distributed to various students, such as science and technology students, social science students, and education students. Therefore, we also observed the differences in student perceptions between students from different backgrounds, such as science and technology students and social science students.

Our research objectives are to analyze and determine student perceptions of the online learning process based on three main questionnaire criteria by implementing a machine learning technique using the Random Forest algorithm. By knowing students' perceptions of the online learning process, the stakeholders could obtain helpful information for improving the online learning process. The results provide a new perspective on data mining and machine learning as tools in Education 4.0. Therefore, to design a better learning process that meets lecturers' and students' expectations, the authors propose that these study results could contribute to online learning development.

\section{Literature Review}

Learning methods need to be continuously developed, either in-class or online, by analyzing student perceptions [1]. Baber [2] conducted a study to determine student satisfaction in online learning using a questionnaire to determine student perceptions. The interaction of lecturers and students is an essential point in the questionnaire. Thus, the person in charge of education can determine whether the entire learning process can help students develop themselves and obtain adequate knowledge [3].

Input from students' perceptions became essential data and was used as helpful information to develop the learning process. Thus, a more comprehensive picture will be obtained to develop the learning process in class and online [4]. With the university's development, both the number of 
students and the study programs offered, more and more data will be collected for various needs, especially for developing the learning process. Therefore, it is necessary to analyze the collected data [5]. This data is in the form of student track records and learning processes.

Analyzing and evaluating large amounts of data requires data mining and machine learning to provide more accurate information. Machine learning algorithms could analyze and examine natural patterns in the data that generate insight and help make better decisions and predictions [6]. The data usually are analyzed based on trial and error, but this approach becomes impossible to adopt when the datasets are large and heterogeneous. Thus, machine learning is used to provide an innovative way to analyze vast volumes of data. By developing fast and efficient algorithms and data-driven models for real-time data processing, machine learning can produce accurate results and analysis [7]. In the education sector, the data mining and machine learning algorithm approaches can provide an overview of the learning process based on student questionnaire data [5]. Several machine learning algorithms that can be used are Random Forest, Support Vector Machine, and Artificial Neural Networks.

Today, the online learning process is widely used. It cannot be separated from the influence of the industrial revolution 4.0. In the world of education, this term is referred as Education 4.0 [8]. One of the characteristics of Education 4.0 is that education is built and developed based on lecturer performance and student perceptions by using data collected from their daily learning activities. Data were stored, processed, and analyzed to become information or knowledge, known as Data Mining [6]. Data analysis relating to the World of Education and its results to provide input to the learning process development is known as data mining in education $[9,10]$.

Nowadays, data are playing a vital role in answering various problems. Data are referred because there is much information extracted from the data's presence. Patil [11] stated that data mining is required to extract information become knowledge. Before data mining discovers knowledge from datasets, some Knowledge Data Discovery (KDD) steps should be performed. Those steps are data preparation, data transformation, data mining, and knowledge discovery [10]. IoT has created an immense need for KDD methodologies because data has become a crucial factor. Here, KDD methodologies are needed for extracting valuable knowledge from data [12].

Borkar et al. [13] also indicated that data mining could analyze datasets from different perspectives and summarize them into valuable information to identify big datasets patterns. Data mining's primary function is to implement techniques and algorithms to detect and extract patterns, artificial intelligence, and visualization techniques [6]. Data mining algorithms and methods are also developed and used in the education sector. Educational Data Mining has been implemented to help the education sector analyze educational data [14].

Educational Data Mining has been implemented in some research areas, such as e-learning systems, innovative tutor applications, text mining in some course outlines, social media to discover how people learn using social media. Educational Data Mining changes raw data into valuable information [10]. A study conducted by Ali [15] showed that data mining applied in the education sector could be used for various research, especially in prediction, classification, clustering, and associations associated with the learning process. Martinez et al. [16] used data mining techniques to analyze students' academic achievement and algorithm and data structure performance. The study was used to infer the students' profiles. The study proved that how data mining can make clusters to categorize students' academic performance.

Some researchers also mentioned the role of data mining and machine learning as a research tool in the field of education, for example, to predict applicants [17], curriculum development [18], study program selection [19], performance lecturers [20]. Kushik et al. [21] studied student performance in the online learning process. The research focused on online test problems. Other researchers use Educational Data Mining to communicate interactively between students and its tutor. It develops intelligent tutor applications. 


\section{Methodology}

To evaluate whether the online learning process is running well, the authors conducted a survey to determine the challenges and difficulties of online learning. The survey includes five main elements considered necessary in the study of independent learning, i.e., self-management aspects, personal efforts, technology utilization, perception of self-role, and perceptions of lecturers' role. Moreover, in this study, the five primary elements were examined further and focus more on three main student perceptions on their learning using an online method. The three students' perceptions are (1) students' perceptions of online lectures, (2) students' perceptions of students' and lecturers' roles in Online learning, such as student independence on learning, learning methods from lecturers, and time management, and (3) access to and use of information technology.

Data were collected from the student survey from the Quality Assurance and Internal Audit Institution (LPMAI) Sanata Dharma University Yogyakarta. From April 8 to 28, 2020, the questionnaire was open for students to share their opinion and perception of the online learning method. The data consist of 25 questions or variables in the form of a Likert scale (1-5), where one is equal to disagree, and five is strongly agree. The 25 questions could be grouped into three main criteria, namely the student perspective, the student and lecturer preparation, and how to access and use information technology for online learning. The respondents were 2667 students from Universitas Sanata Dharma. They come from eight departments: Education, Science and Technology, Economics and Business, Arts, Pharmacy, Psychology, Theology, and Postgraduate. The number of respondents in detail can be seen in Table 1 below:

Table 1. Number of respondents from each department

\begin{tabular}{lc}
\hline \multicolumn{1}{c}{ Departments } & Number of Respondents \\
\hline Education & 1227 \\
Science and Technology & 426 \\
Economics and Business & 346 \\
Arts & 241 \\
Pharmacy & 240 \\
Psychology & 106 \\
Theology & 54 \\
Post-Graduate & 27 \\
\hline
\end{tabular}

With 25 features and 2667 respondents, a questionnaire data result could be complex datasets. The dataset would predict students' perception of online learning and discover the influencing variable for each prediction. Machine learning techniques were performed not only to find the variable importance but also to obtain predictive accuracy. The data were processed by following the steps in $\mathrm{KDD}$. The raw data in the form of a questionnaire were modified and restructured so that data mining tools could read it. As mentioned above, the data was collected from LPMAI's questionnaire results, then examined whether there was a missing value. The authors also selected which variable would become a target data or the dependent variable based on the research questions. Furthermore, data normalization was performed by changing data into maximum and minimum data values in the data transformation steps. The results were between zero and one. The dataset was separated into $80 \%$ training and $20 \%$ testing dataset.

This study applied a Random Forest algorithm using Python Scikit Learn and $\mathrm{H} 2 \mathrm{O}$ to analyze data. Random forest was selected for determining the variable importance and calculating RMSE. Python and $\mathrm{H} 2 \mathrm{O}$ are powerful and popular language programs in machine learning techniques. Random forests are a method of averaging multiple profound decision trees then trained on different parts of the same training set to reduce the variance. Briefly, the algorithm can be described as follows: the random forest operator generates a set of random trees, the class generated from the classification process is selected from the most class generated by the random tree that exists [22]. Tatsumi et al. [23] described that random forests had computationally excellent performance. The random forest has proven as an effective and versatile machine learning method because this 
algorithm could predict and provide high accuracy and precision in data analysis. Therefore, random forest is the most powerful and popular supervised machine learning algorithm for predictions. Even though some benefits in using random forest were found, some disadvantages were also recognized. For example, the features need to have some predictive power else, they would not work correctly, trees' predictions need to be uncorrelated, and random forest algorithm appears as Black Box: it is to know what is happening, so different parameters and random seeds need to be performed to change the outcomes and performance [24]. To find out the prediction model, the data processing results were focused on students' perceptions of the online learning process, which includes three main criteria in the questionnaire.

In this study, the calculation was conducted to find the RMSE (Root Mean Square Error) values, which is used to predict the validation dataset's dependent variable. A low RMSE value indicates a better degree of similarity between the predicted data and the actual data. The RMSE value is also needed to determine the variable importance. The RMSE is calculated using the following formula:

$$
R M S E=\sqrt{\sum_{i=1}^{n} \frac{\left(\breve{Y}_{i}-Y_{i}\right)^{2}}{n}}
$$

$n$ is the number of observations, $Y_{i}$ is the observed values, and $\check{Y}_{i}$ is the predicted values. Next, the variable importance is needed to overview the independent variables that influence the RMSE value. To understand the online learning implementation better, then the importance of variables must be the focus of change.

\section{Finding and Discussion}

We analyzed data using the Random Forest algorithm to determine which independent variables had the most influence on student perceptions in terms of:

1. Students' perceptions of success in their study use online learning. One indicator of success for students is completing studies in the current semester using online learning. How can students be independent in their studies by managing themselves and their time so that they are able and successful in completing their studies? Can students feel comfortable with online learning with this independence?

2. Students' perceptions of lecturers. Have students seen that lecturers can adapt learning methods so that they are more relevant to online learning? Furthermore, do students sufficiently helped in the learning process because the lecturers are already involved in the online learning process, especially in providing feedback to students quickly?

3. Students' perceptions of ICT. Does technology become a supporting factor in helping students complete their studies and access broader knowledge through online learning?

These three student perceptions were detailed into six questions as follows:

a) I feel comfortable participating in online learning (questionnaire no.13) associated with the student independence factor.

b) I want to complete the semester (questionnaire no. 3) related to the student independence factor.

c) Lecturers have adapted learning methods so that the materials are more relevant to online learning (questionnaire no. 22).

d) I feel comfortable participating in online learning (questionnaire no. 13), which relates to how the lecturer has adapted the materials and learning methods and provides quick feedback.

e) I want to complete this semester (questionnaire no. 3) related to having a smartphone or laptop, having the right skills, and knowing how to use the gadget.

f) I can access broader knowledge through online learning (questionnaire no. 16). 


\subsection{I feel comfortable following online learning (questionnaire no.13).}

The RMSE value obtained for this model is 0.9713 . The calculation result of variable importance for question no.1 is as shown in Figure 1. It is interesting that to answer, "Do students feel comfortable participating in online learning?" has a correlation and is influenced sequentially by variables with the questionnaire questions number (20), number (4), and number (18). The three questionnaire questions are: I am comfortable communicating the difficulties and challenges I face to the lecturer (no.20). I can manage my feelings/emotions (no. 4). I am open to learning activities delivered by lecturers (no. 18). Results are as seen in Figure 1 below.

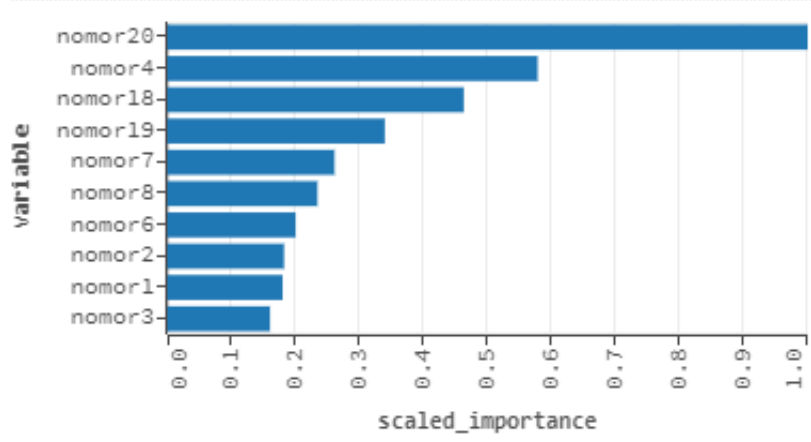

Figure 1. Question 1 variable importance

The results described the phenomenon of the importance of creating well-being among students. Psychological studies in the mid-2000s showed the importance of well-being as an essential component in the success of education itself [25]. Psycho-social well-being is characterized by an educational condition that is free from physical and mental violence. In its implementation, lecturers provided complete access to communication and problem-solving. Thus, students do not feel separated from their lecturers because of this kind of emotional closeness. It becomes the basis of the formation of mutual trust.

Three main elements to build this kind of well-being are communication skills, social tolerance, and creativity [25]. Communication skills that support the creation of well-being are created due to mutual trust, kindness, communication skills, democratic ways, the ability to manage feelings, and the ability to manage strategies and techniques for interacting with others. Social tolerance is determined by honest recognition and respect for others, the readiness of a moral attitude to interact positively with others. Creativity is defined as students' ability to manifest themselves, develop abilities and skills for self-fulfillment while creating an environment that is socially safe and comfortable for themselves and others. Implementing learning, closeness, and comfort to the teacher will be further strengthened by meaningful feedback [26].

\subsection{I want to succeed in completing this semester (questionnaire no.3).}

The RMSE value for question no. 2 is 0.618 , and the variable importance is presented as follows in Figure 2:

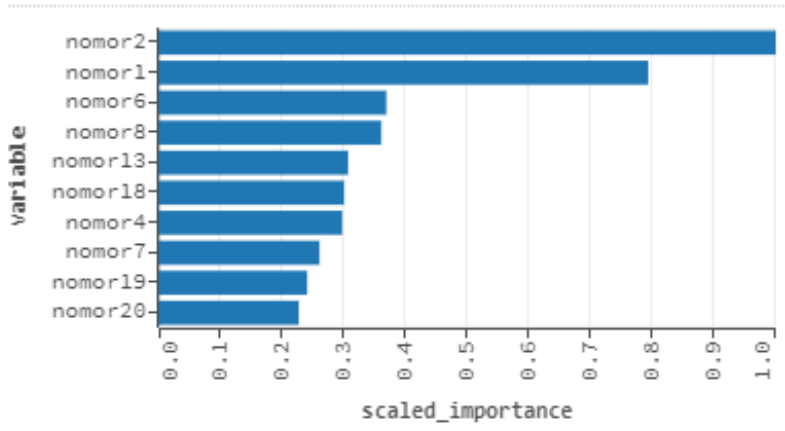

Figure 2. Question 2 variable importance 
The three primary variables in answering the question "students still want to be successful in completing this semester" are: I am willing to learn more for optimal results (no. 2), I realized my strengths and weaknesses as a student (no. 1), I set a priority scale to determine what I should do (no. 6). Learning performance between students who do well and those who ultimately fail has been a concern of researchers since the mid-1970s. What makes a child successful compared to those who are not successful in learning? The main differences between successful learners and those failing in learning relies on the way of learning. Doing well in learning performance shows the ability to selfmanage (self-regulation). Their metacognitive skills are much better because they could assess their strengths and weaknesses. They can find solutions and compensation that can overcome their weaknesses or shortcomings [26]. The ability to self-regulate metacognitive skills refers to a series of interrelated activities, including the ability to set learning goals and orientation; determining the strategies that will be used to achieve the stated goals; management of various existing resources; the implementation; appropriate reactions to feedback from others; and the meaning of the resulting product. If a series of skills has never been possessed or developed, students will undoubtedly fail to develop regulation of metacognition skills.

\subsection{Lecturers have adapted learning methods to be more relevant to online learning (questionnaire} no. 22).

Question no. 3 is related to whether the lecturer has adapted the learning method to be more relevant to online learning (questionnaire no. 22). The RMSE result for this calculation is 0.522 , with the main supporting factors: Lecturers have adapted the material to be more relevant to online learning (no. 21), Lecturers provide informative feedback (no. 25), and Lecturers provide feedback (feedback) quickly for online assignments (no. 24). Results are as shown in Figure 3.

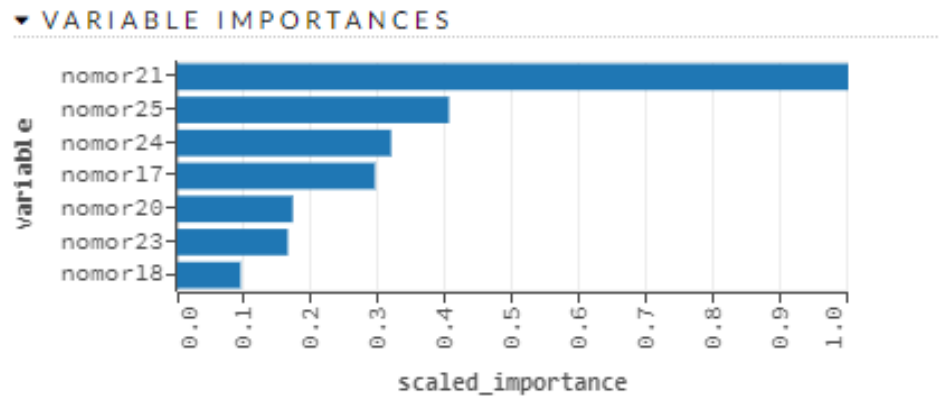

Figure 3. Question 3 variable importance

There are two points in this section: the importance of lecturer mediation as the party that constructs meaning (namely by simplifying complexity) and the importance of lecturers providing meaningful feedback. Yevelson [27] reminded that the condition of the digital era would be increasingly marked by the condition of "a world where vast amounts of unfiltered data are available online."

American Library Association described that digital literacy refers to defining what sorts of information are needed. For example, locate the needed information efficiently; evaluate information and its sources critically; incorporate selected information into one's knowledge base; understand the economic, legal, social issues surrounding the use of information; and access and use information ethically and legally. Of course, it becomes more interesting when the data shows that students still need lecturers to summarize or make the material easier to understand. This is partly due to the lack of pre-digital literacy that they brought before entering the digital area, which is getting stronger in today's context. It is proven that students do not have the freedom to determine what is good and right and cannot use their thinking skills to independently determine essential things that they consider essential to be pursued. 
The next thing is the nature of the feedback (feedback). Feedback is vital in facilitating learning. However, feedback in learning cannot be simplified as a knowledge transmission mechanism [26]. On the one hand, feedback that supports the growth of knowledge has a unique set of characteristics, which support the achievement of constructivist learning, and at the same time, increase the potential for metacognitive development among students. On the other hand, students could process feedback appropriately and usefully, so they need to master feedback literacy. Feedback is defined as "a process through which learners make sense of information from various sources and use it to enhance their works." They regretted that students still did not have sufficient skills to understand the meaning of feedback (feedback literacy) [28]. However, in our study, teacher feedbacks have the second and thirdranked based on student perception. This result confirmed what Martin et al. conducted. They claimed that communication and interaction between students and teachers greatly influence successful online learning, especially when teachers respond to students' problems [29].

\subsection{I feel comfortable following online learning (questionnaire no 13).}

The question is associated with how the lecturer has quickly adapted the material, learning methods, and feedback. The RMSE results obtained are 0.894 , and the primary variable results are as shown in Figure 4. The three main factors that correlate to 'Students Feel Comfortable in Online Learning' are: Lecturers have adapted the material so that it is more relevant to online learning (no. 21), I get feedback from lecturers quickly through online learning (no. 17), and Lecturers have adapted learning methods so that they are more relevant to online learning (no. 22).

Conducting online learning has an impact on changes in teaching materials. In contrast to classical learning, where teachers and students meet face-to-face, online learning assumes that face-toface meetings take place synchronously and asynchronously through various digital media. Therefore, teachers must change teaching materials and adapt them to the online tools used, such as LMS, social media, YouTube, and virtual labs [30]. In other words, the changing media from physical to digital forms can make students feel comfortable and confident to learn using online learning.

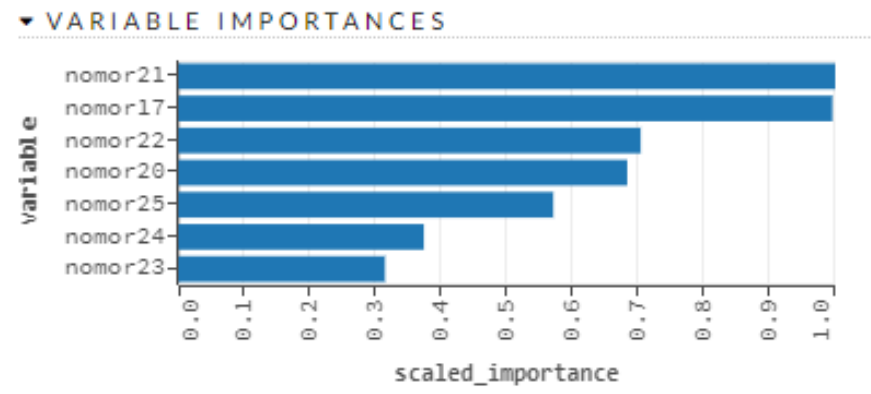

Figure 4. Question 4 variable importance

Data related to student preferences regarding the role of lecturers in adapting learning material to increase relevance to online learning reflects the tension that has been unconsciously built up so far. On one hand, this shows the lecturers' concern for their students, prioritizing well-being orientation or comfort [25]. However, at the same time, it also describes a strong indication of the existence of four fundamental weaknesses in students, which include: (a) the level of learning independence among students is still relatively low among students [31], (b) low capacity in mastering digital literacy [27], (c) weak ability of students in self-regulation or metacognitive skills [26], and (d) surface-oriented solid habituation understanding [32].

4.5. I want to be successful in completing this semester (questionnaire no. 3).

Having intelligent devices and knowing how to use them is related to this question. The RMSE result for this data target is 0.705 as shown in Figure 5. 


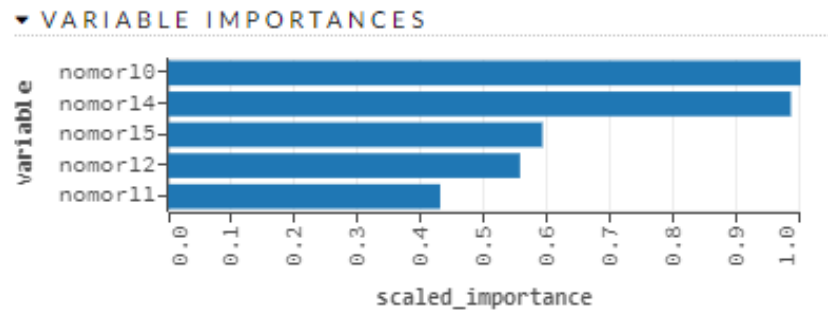

Figure 5. Question 5 variable importance

Three main variables correlate to 'Students Want to Continue to Succeed in Completing this Semester,' i.e., I have sufficient technology equipment (handphone and computer). I know how to use technology tools for online learning (e.g., handphone, computers, Google Classroom, Zoom, WA). I have good skills to use various technology tools for online learning.

The student's high self-confidence is related to completing their studies in the online learning process. This factor is mainly determined by the availability of supporting tools in the form of technological equipment, and at the same time, the ability to use various existing technological tools. Studies published recently have confirmed the strength of feelings, isolation, and growing frustration because of this learning experience in the context of the Covid-19 Pandemic [33]. The lack of access to information technology due to unsupported equipment and the internet creates frustration that decreases students' motivation and self-confidence. The loss of encounters with lecturers and fellow students has erased the social structure in which students could share their burdens and care for one another.

4.6. I can access broader knowledge through online learning (questionnaire no. 16).

The RMSE result for this calculation is 0.769 , and the variable importance shows that question no 17 becomes the primary variable as shown in Figure 6.

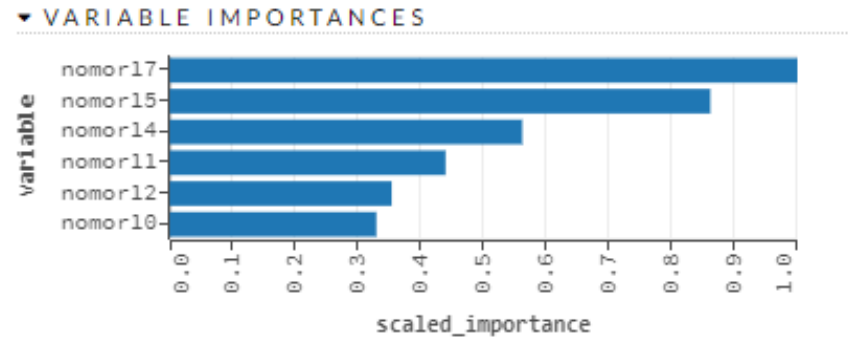

Figure 6. Question 6 variable importance

The three main influence variables are I get feedback from lecturers quickly through online learning (no. 17), I have good skills to use various technological tools for online learning (no. 15), and I know how to use technology tools for online learning (e.g., handphone, computers, Google Classroom, Zoom, WA) (no. 14).

These three main influencing variables show that technology and its use become one of the main points in online learning. It also presupposes that technical support was an essential factor critical to guaranteeing student satisfaction at online classes. Nambiar [34] reported a similar finding that students showed dissatisfaction with their courses when instructors were unavailable to provide technical support and when they had limited technical skills on technology tools for online learning.

The lecturer's fast learning feedback is crucial, and this is closely related to self-efficacy for skills in using various existing information technologies. This is not separated from the fact that information technology is becoming a mediator, which has an increasingly significant role in this online learning mechanism. Referring to various research findings with the Cultural-Historical Activity Theory (CHAT) perspective, all human activities are believed to have originated and grown in a social 
context $[35,36]$. Information technology in online learning mechanisms is a fundamental component in constructing knowledge based on human consciousness (consciousness-related knowledge). In CHAT, the primary unit of analysis is students (as the main subject) who carry out various activities (objects) to achieve outcomes. Activity systems in the context of online learning are mediated by five other primary elements, i.e., tools, rules, community, division of labor, and object (s) [36]. Expressly, the tools refer to two levels: primary tools (cellphones, computers, internet, books, study rooms) and secondary tools (experiences, language skills, ideas, hopes, motives). The feedback given by the lecturer is crucial as a form of community support, and the presence and skills of the self in utilizing various information technologies play a very central role in its role in online learning.

\section{Conclusion}

The results showed that three things greatly influenced students' perceptions of comfort in implementing distance learning. The closeness between students and lecturers shows the first perception. This is expressed in the hope that lecturers can provide feedback quickly. In the distance learning process, the lecturer-student relationship is a crucial factor that will significantly influence the learning process. The second is a matter of material adaptation. Students hope that the learning material needs to be changed and adapted to the distance learning process or method. In other words, lecturers are asked to change the format for delivering learning material. The third relates to the use of technology as a distance learning support system. Students consider that mastery of technology is essential in the distance learning process. In this case, the decision-makers in the university scope can help and facilitate students with training or infrastructure that is more "user friendly" to quickly master technology and be used to access this distance learning better. In the future, it is necessary to re-examine what kinds of materials and technologies can be used so that they are more acceptable to students as a learning process to gain broader knowledge. It is also necessary to learn about how to prepare student personalities, especially concerning student independence in the learning process.

\section{Acknowledgement}

The authors would like to thank LPPM Sanata Dharma University Yogyakarta for providing the opportunity to research student perceptions of the distance learning process during the Covid-19 pandemic.

\section{References}

[1] V. Puncreobutr, "Education 4.0: New challenge of learning," St. Theresa Journal of Humanities and Social Sciences, vol. 2(2), 2016.

[2] H. Baber, "Determinants of students' perceived learning outcome and satisfaction in online learning during the pandemic of COVID-19," Journal of Education and e-Learning Research, vol. 7(3), pp. 285-292, 2020.

[3] K. Wang and C. Zhu, "MOOC-based flipped learning in higher education: students' participation, experience and learning performance," International Journal of Educational Technology in Higher Education, vol. 16(1), pp. 1-18, 2019.

[4] R. Owston, D. York, and S. Murtha, "Student perceptions and achievement in a university blended learning strategic initiative," The Internet and Higher Education, vol. 18, pp. 38-46, 2013.

[5] J. Vanthienen and K. De Witte, "Data Analytics Applications in Education," CRC Press, 2017.

[6] J. Han, J. Pei, and M. Kamber, "Data mining: concepts and techniques," Elsevier, 2011.

[7] M. Frey and M. Larch, "Statistical Learning in the Age of "Big Data" and Machine Learning," 2017.

[8] A.A. Hussin, "Education 4.0 made simple: Ideas for teaching," International Journal of Education and Literacy Studies, vol. 6(3), pp. 92-98, 2018.

[9] B. Cope and M. Kalantzis, "Big data comes to school: Implications for learning, assessment, and research," AERA Open, vol. 2(2), pp. 2332858416641907, 2016. 
[10] J.M. Zain and T. Herawan, "Data Mining for Education Decision Support: A Review," International Journal of Emerging Technologies in Learning, vol. 9(6), 2014.

[11] S.M. Patil and P. Kumar, "Data mining model for effective data analysis of higher education students using MapReduce," IJERMT, ISSN, vol. 6(4), pp. 2278-9359, 2017.

[12] C.K. Nwagu, O.C. Omankwu, and H. Inyiama, "Knowledge Discovery in Databases (KDD): an overview," Int J Comput Sci Inf Secur (IJCSIS), vol. 15(12), pp. 13-16, 2017.

[13] S. Borkar and K. Rajeswari, "Predicting students academic performance using education data mining," International Journal of Computer Science and Mobile Computing, vol. 2(7), pp. 273279, 2013.

[14] C. Romero and S. Ventura, "Educational data mining and learning analytics: An updated survey," Wiley Interdisciplinary Reviews: Data Mining and Knowledge Discovery, vol. 10(3), p. e1355, 2020.

[15] D.M.M. Ali, "Role of data mining in education sector," International Journal of Computer Science and Mobile Computing, vol. 2(4), pp. 374-383, 2013.

[16] D.L.R. Martínez, et al., "Academic performance profiles: a descriptive model based on data mining," European Scientific Journal, vol. 11(9), 2015.

[17] H.A. Mengash, "Using data mining techniques to predict student performance to support decision making in university admission systems," IEEE Access, vol. 8, pp. 55462-55470, 2020.

[18] W. Jie, et al. "Application of educational data mining on analysis of students' online learning behavior," in 2017 2nd International Conference on Image, Vision and Computing (ICIVC). IEEE, 2017.

[19] A.A. Kardan, et al., "Prediction of student course selection in online higher education institutes using neural network," Computers \& Education, vol. 65, pp. 1-11, 2013.

[20] P. Kamal and S. Ahuja, "Academic performance prediction using data mining techniques: Identification of influential factors effecting the academic performance in undergrad professional course," in Harmony Search and Nature Inspired Optimization Algorithms, Springer, pp. 835-843, 2019.

[21] N. Kushik, N. Yevtushenko, and T. Evtushenko, "Novel machine learning technique for predicting teaching strategy effectiveness," International Journal of Information Management, 2016.

[22] T. Hastie, R. Tibshirani, and J. Friedman, "The elements of statistical learning: prediction, inference and data mining," Springer-Verlag, New York, 2009.

[23] K. Tatsumi, et al., "Crop classification of upland fields using Random forest of time-series Landsat 7 ETM+ data," Computers and Electronics in Agriculture, vol. 115, pp. 171-179, 2015.

[24] A. Hjerpe, "Computing Random Forests Variable Importance Measures (VIM) on Mixed Numerical and Categorical Data," 2016.

[25] P.A. Kislyakov, et al., "Monitoring of education environment according to the socialpsychological safety criterion," Asian Social Science, vol. 10(17), p. 285, 2014.

[26] R.E. Bennett, "Formative assessment: A critical review," Assessment in education: principles, policy \& practice, vol. 18(1), pp. 5-25, 2011.

[27] A. Yevelson-Shorsher and J. Bronstein, "Three perspectives on information literacy in academia: Talking to librarians, faculty, and students," College \& Research Libraries, vol. 79(4), p. 535, 2018.

[28] D. Carless and D. Boud, "The development of student feedback literacy: enabling uptake of feedback," Assessment \& Evaluation in Higher Education, vol. 43(8), pp. 1315-1325, 2018.

[29] F. Martin, C. Wang, and A. Sadaf, "Student perception of helpfulness of facilitation strategies that enhance instructor presence, connectedness, engagement and learning in online courses," The Internet and Higher Education, vol. 37, pp. 52-65, 2018.

[30] K. Kuosa, et al., "Interactive visualization tools to improve learning and teaching in online learning environments," International journal of distance education technologies (IJDET), vol. 14(1), pp. 1-21, 2016. 
[31] P. Benson, "The philosophy and politics of learner autonomy," in Autonomy and independence in language learning. Routledge, pp. 18-34, 2014.

[32] J.B. Biggs and K.F. Collis, "Evaluating the quality of learning: The SOLO taxonomy (Structure of the Observed Learning Outcome)," Academic Press, 2014.

[33] G. Basilaia and D. Kvavadze, "Transition to online education in schools during a SARS-CoV-2 coronavirus (COVID-19) pandemic in Georgia," Pedagogical Research, vol. 5(4), 2020.

[34] D. Nambiar, "The impact of online learning during COVID-19: students' and teachers' perspective," The International Journal of Indian Psychology, vol. 8(2), pp. 783-793, 2020.

[35] M.B. Postholm, "Methodologies in Cultural-Historical Activity Theory: The example of school-based development," Educational Research, vol. 57(1), pp. 43-58, 2015.

[36] K.A. Foot, "Cultural-historical activity theory: Exploring a theory to inform practice and research," Journal of Human Behavior in the Social Environment, vol. 24(3), pp. 329-347, 2014. 